\title{
State family policy in France and Russia
}

\author{
Nadezhda Anatolievna Shaidenko ${ }^{11}$, Elena Yakovlevna Orekhova ${ }^{2}$, Alexander Nikolaevich \\ Sergeev $^{3}$, and Svetlana Nikolaevna Kipurova ${ }^{1}$ \\ ${ }^{1}$ The Advanced Training and Professional Retraining Institute of Education Professionals of Tula \\ Region, Tula, Russia \\ ${ }^{2}$ Moscow City University, Moscow, Russia \\ ${ }^{3}$ Tula State Lev Tolstoy Pedagogical University, Tula, Russia
}

\begin{abstract}
State family policy and its important direction, which is the improvement of the living conditions of orphans and children left without parental care, require constant updating due to socio-economic and political circumstances. Changes should concern both the state level and the level of specific regions. The improvement of the forms and methods of relations between the state, family and children in a particular country is possible with the consideration of the advanced achievements and miscalculations of other states in this policy. Therefore, it is highly important for the theory and practice of the development of Russian family state and regional policy to study the experience of France. The study made it possible to draw conclusions about the specifics of state policy in the formation of family and childhood in France. In this period, family policy in France has gone from exclusion from the family by the school to a discourse of cooperation. Particular attention is paid to the French School Orientation and Reform Act of June 8, 2013, of particular interest. It recognizes the importance of establishing partnerships between the school and the family and proposes measures of cooperation between school and family, some of which are interesting for contemporary Russian reality. The article shows the advantage of modern Russian family state policy by characterizing its goals, principles and objectives defined in the main regulatory documents of the last decade. The materials of the article are of practical value for legislators and heads of social services of different levels, specialists of educational authorities, social protection, guardianship and trusteeship. The article is of interest to teachers and students of pedagogical universities.
\end{abstract}

Keywords: state family policy; orphans; children at risk, family-school relationships

\section{Introduction}

The change in attitude towards the period of childhood in human society took place towards the recognition of its special significance in the formation of the personality, the idea of the intrinsic value of the period of childhood. The growing importance of the issue of

${ }^{1}$ Corresponding author: nashaidenko@gmail.com 
responsibility of adults to children is due to these ideas. There are problems of supporting children, providing them with conditions for all-around development, a smooth entry into adulthood [1].

In recent years, social and pedagogical support for family and childhood has been considered a priority area for the Russian state and society [2]. An important priority for the successful development of orphans is their placement in families, that is, efforts are required to help the family as the basis of the state [3]. To improve the state family policy, it is important not only to take into account the peculiarities of the country's economic, social, demographic policy, but also to rely on the positive experience of other states [4].

The purpose hereof is to study the relationship between families and schools in France, since it is in this country that family policy is most developed and ambitious.

\section{Methods}

The main research methods used in the study are the diachronous-synchronous comparison of the past and present state of family and school in France, the analysis of the main regulatory documents; the identification and characterization of factors influencing the relationship between family and school; the comparative characteristics of attitudes towards children at risk in Russia and France.

\section{$3 \quad$ Results}

A detailed study of the problem of family-school relation is presented using the example of France [5]. This research vector is due to the fact that France is one of the countries with the most developed and large-scale family policy. Therefore, there is reason to consider the most controversial, interesting, productive European experience aimed at supporting the family, creating favorable conditions for the education and upbringing of children using the example of this country [6].

The family-school relationship in France has always been complicated. Historians, for example, such as the "guru" of European historical pedagogy Aries F., argue that in the Middle Ages, parents did not show any interest in their offspring [7]. The educational discourse with the concepts of responsibility of families and schools appeared only in the 18th century. The child became an object of care for his hygiene, physical and mental development, an object of protection from threats to his life and health. The institutions with the authority to oversee the proper education of children emerged. The school began to act as an institution that fulfills the obligations of the family in the education and upbringing of children.

For immersion in research issues, the authors studied the period between 1882 and 2013, which made it possible to carry out the most dynamic (diachronous-synchronous) comparison of the past and present of the family and school within this framework.

The law of March 28, 1888, provides for compulsory primary education in the country. An analysis of the legislative texts of this period, as well as the corresponding scientific research, shows that, despite the monumentality of the laws of the $90 \mathrm{~s}$ of the $19^{\text {th }}$ century, which established the fundamental principles of freedom, obligation and secularity of public education in the country [8-12].

Tough measures for parents and students who risk violating the requirements set out in the law are associated with truly revolutionary changes that took place in this period in the country, with the reform of the education system itself. The followers of the legislators of 
revolutionary France Ferry and Bert called for an end to the age-old tradition of associating primary schools with mercy and charity institutions [13]. It was proposed to consider the elementary school as the basis for the development of the entire educational system, as the foundation, which was mentioned in the famous Condorcet plan.

According to the authors, there is a subordinate context in other documents, where the legal responsibility of parents for a child's non-school attendance is considered. Four "disrespectful" non-attendance per month caused the following sanctions against parents: discussion of parents at the school council; in case of failure to appear - public condemnation of the "image of the family" by the placement of a description of the inappropriate supervision of the children by the family with detailed indications of names, surnames, addresses, occupations, etc. of the parents who violated the law, on the doors of the city hall. If this measure did not work, then an appeal to the magistrate followed, and the family was sentenced to a fine of 10-15 francs or even imprisonment of one of the parents for a period of 5 days.

During the times of the Third Republic, the great principles of secularism, Kantian philosophy, and O. Comte's positivism were the ideological basis of school education and upbringing. It made it possible to "withdraw", "drive" the children out of the influence of the church and family, immersing them in the bosom of the school. According to J. Ferry, only school had the right to teach and educate. "School was created in order to save a child from the love of parents ...", "family teaches and educates poorly ...", "most parents are ignorant, superstitious, their thinking is full of obscurantist prejudices ..." [14]. The father of French sociology, E. Durkheim, had a tremendous influence on the formation of the ideology of separating the child from the school, that is, the state, from the family. "School is a serious thing entrusted to teachers, educated and enlightened people, while parents, especially mothers, are subject to dark religious forces ..." [15].

Meanwhile, in the period between the two world wars (1918-1939), two dominant factors somewhat soften the situation of the emerging confrontation between family and school. The first is the creation of the "Code of Soleil", a kind of "Bible" for teachers, a real set of moral principles and practical actions of the teacher. The second is the creation of the first association of pupils' parents.

The discourse of suspicion and mistrust, the alienation from family by school is transformed in the code into a discourse of cooperation [16].

The circular of the Ministry of Public Education of 1932 instructed the rectors of the academies to encourage the administration of educational institutions to cooperate: teachers - with the parents of pupils, the administration - with the representatives of parental associations, which are regarded as organizers of parental masses for the school [17].

The texts reveal the conceptual evolution of the relationship between school and parents since the time of J. Ferry's laws, from complete excommunication of the family from school to institutionalized requirements for involving parents in the school life of their children. The evolution of professional pedagogical training, socio-professional values, corporate ethics, etc. played a significant role in this matter.

One cannot but dwell on the socio-political context of this period, on the coming of private, non-state education to the fore from the depths of the reforms at the turn of the $19^{\text {th }}-20^{\text {th }}$ centuries, from the "school of compromise". This was facilitated by the law of December 31, 1959 "On contractual aid from the state to private educational institutions", which annuls some legislative provisions of the Third Republic.

On February 13, 1960, a national appeal against this law took place, initiated by the National Committee of Secular Organizations, supported by the Federation of Parents' Councils. 
A significant factor in the context of the relationship between parents and schools in the period under review is the emergence of the F. Mitterrand family and school support program. The Unified State Service of Public Education (SPULEN) was established for this purpose.

It was during this period that a kind of peak of the contradiction between the desire of legislators to strengthen the influence of parents within the educational institution and the resistance of the educational system to these changes reached. The battles that have arisen are eagerly covered in the media, and are developed in studies with relevant topics: "School consumers" by Ballion [18], "Misunderstanding" by Dubet [19], "L'école ou la guerre civile" by Meirieu and Guiraud [20], "School versus Parents" by Gayet [21] and others.

Since that time, the situation in the process of integrating family and school has remained practically unchanged.

In this a century and a half period, small by historical standards, in our opinion, the evolutionary development of relations between the school and parents where the conceptual discourse of the family and the school is changing consistently with some cumulative effect, is perfectly traced. The change in parental status at school (parents - subordinates, parents - consumers, parents - clients, parents - partners) incited significant changes in this area, enshrined in the 2013 law. The text of the Interdepartmental Ministerial Circular dated October 15, 2013, which spelled out the need for strengthening cooperation between parents and school in the territories, is highly interesting. A new period of family-school relations, which considers co-upbringing and co-education of children in the context of cooperation and equal partnership, has begun in the country.

\section{Discussion}

The study of a half-century historical period has shown the evolutionary nature of the relationship between school and parents. First of all, the status of parents has changed from the status of subordinates, consumers, clients, to the status of partners. In terms of the role of the family, its relationship with the school has also changed from the complete exclusion of the family from school life to the requirement of mandatory parental participation in the lives of children.

The problem of family-school relations, which remained practically unchanged until the 60 s of the twentieth century, is undergoing significant changes under the influence of the following factors:

- mass character and democratization of education due to the increase in the duration of compulsory education up to 16 years. In this context, educational discourse is enriched with concepts: social lift, educational route, choice;

- the recognition of the child as the future of the family, the implementer of its plans by society. In this context, the concept of "conflict" appears, where society takes the side of the child and defends his interests, where the adult society has split, where the child's word and opinion prevail over the teacher's;

- the evolution of the cultural and educational level of parents;

- the loss of prestige of the teaching profession [22].

At the end of the 70 s of the $20^{\text {th }}$ century, the interaction between family and school was structurally designed and it has become much more complicated by now.

\section{Conclusion}


Despite certain success of France in the field of state family policy and the possibility of transforming a number of its main ideas in Russian conditions, the priorities, forms and methods of Russian state policy in the field of family and childhood should be based on fundamental national values.

At the present stage, the priorities of state policy in relation to family and childhood include the establishment of traditional family values and family lifestyle, the revival and preservation of spiritual and moral traditions in family relations and family education, the creation of conditions for ensuring family well-being, responsible parenting, increasing the authority of parents in the family and society, as well as maintaining the social stability of each family [23].

The traditional family values, proclaimed by the Concept, include the values of marriage, understood as the union of a man and a woman, based on state registration with civil registration authorities, concluded for the purpose of creating a family, birth and (or) joint education of children, based on care and respect to each other, to children and parents, characterized by voluntariness, stability and common life, associated with the mutual desire of spouses and all family members to preserve it.

It is no coincidence that in the new Constitution of the Russian Federation, a close attention is paid to the family, according to Art. 38 "Motherhood and childhood", family is under the state protection [24].

The article was drawn up with the support of the Government of the Tula region, grant in the field of science and technology in 2020 on the topic: "Tula regional policy in relation to orphans and children left without parental care: history, state and development trends in the interests of the region" (resolution of the Tula government region dated 10.09.2020 No. 541, contract No. DS / 169 dated 29.10.2020)

\section{References}

1. E.Ya. Orekhova, N.A. Shaidenko, A.V. Sergeeva, The Sci. Opin. 6-7, 103-106 (2016)1

2. V.A. Anikin, Yu.P. Lezhnina, S.V. Mareeva, E.D. Monit. Pub. Opin. 3 (2019). https://doi.org/10.14515/monitoring.2019.3.19

3. E.L. Shilkina, V.V. Enina, Bul. South-Rus. Tech. Univ. Ser.: Soc.-Econ. Sci. 13(6), 127-135 (2020). https://doi.org/10.17213 / 2075-2067-2020-6-127-135

4. O.G. Isupova, Demog. Rev. 7(3), 51-83 (2020). https://doi.org/10.17323/demreview.v7i3.11636

5. I.V. Ponkin, Law Edu. 2, 85-96 (2004)

6. M.V. Yachmeneva, World of Sci. Ser.: Soc., Phil., Cult. Stud. 10(4), 52 (2019)

7. Ph. Aries, L'enfant et la vie familiale sous l'Ancien Régime [The child and family life under the old regime] (Le Seuil, Paris, 1973)

8. L. Schwartz, Archives du ministère de l'Éducation nationale: Nouveau Code de l' instruction primaire [Archives of the Ministry of National Education: New Code of primary education] (Hachette, 1889, 1898, 1930)

9. L. Gobron, Législation et jurisprudence de l'enseignement public et privé [Legislation and jurisprudence in public and private education] (Librairie J.-B. Sirey, Paris, 1906)

10. Bulletin administratif du ministère de l'Instruction publique [Administrative bulletin of the Ministry of Public Instruction], 2722 (Paris, 1932) 
11. L. Dion, Recueil complet de la législation de l'enseignement secondaire: (règlements codifiés) [Comprehensive compendium of secondary education legislation: (codified regulations)] (Papeterie générale des écoles, Sartiaux, Rouvière et Cie, 1928)

12. L. Cros, R. Deveze, Manuel de législation à l'usage des établissements du second degré [Manual of legislation for secondary schools] (Paris, 1945)

13. K.A. Fedulova, Young Sci. 27(131), 627-630 (2016)

14. J. Ferry, sa vie, son œuvre, sa famille. Les Guides du musée de Saint-Dié [His life, his work, his family. The Guides of the Museum of Saint-Dié] (Imprimerie municipale, 1981)

15. S.P. Turner, Emile Durkheim: Sociologist and Moralist (Routledge, 1993)

16. Archives du Syndicat des enseignants de l'UNSA: - Code Soleil "Le livre des instituteurs" [Archives of the UNSA Teachers 'Union: - Code Soleil "The book of teachers"] (Éditions Sudel, 1929, 1937, 1947, 1977)

17. L' école libératrice [The liberating school], 22, 12 (Paris, 1960)

18. R. Ballion, Les Consommateurs d'école [School Consumers] (Laurence Pernoud, 1982)

19. F. Dubet, Le Malentendu [Misunderstanding] (Textuel, Paris, 1997)

20. P. Meirieu, M. Guirau, L'école ou la guerre civile [School or Civil War] (Editions Plon, Paris, 1997).

21. A. Gayet, L'École contre les parents [School versus parents] (INRP, Paris, 1999)

22. La place et le rôle des parents dans l' école [The place and role of parents in school]. Accessed on: July 28, 2021. [Online]. Available:

https://www.education.gouv.fr/la-place-et-le-role-des-parents-dans-1-ecole-40874

23. A.M. Aksenov, N.A. Shaidenko, S.N. Kipurova, Opyt i tendentsii gosudarstvennoi podderzhki detei- sirot $\mathrm{v}$ Rossii i za rubezhom [Experience and trends in state support for orphans in Russia and abroad] (TPPO, Tula, 2018)

24. Konstitutsiya Rossiiskoi Federatsii (prinyata vsenarodnym golosovaniem 12.12.1993 s izmeneniyami, odobrennymi v khode obshcherossiiskogo golosovaniya 01.07.2020) [The Constitution of the Russian Federation (adopted by popular vote on 12.12.1993 with amendments approved during a nationwide vote on 01.07.2020)]. Accessed on: July 28, 2021. [Online]. Available: http://www.consultant.ru/document/cons_doc_LAW_28399/ 